\title{
Nuclear Pedigree Criteria of Suspected HNPCC
}

\author{
Józef Kładny', Gabriela Möslein², Torben Myrhøiं, Grzegorz Kurzawski', Anna Jakubowska ${ }^{4}$, Tadeusz Dębniak4, \\ Woiciech Petriczko', Michał Kozłowski', Tariq Al-Amawi ${ }^{5}$, Marek Brzosko ${ }^{6}$, Jacek Fliciński ${ }^{6}$, Arkadiusz Jawieńn', \\ Zbigniew Banaszkiewizz', Piotr Rychter ${ }^{8}$, Jan Lubińnki ${ }^{4}$
}

International Hereditary Cancer Center: 'Department of Surgical Oncology; ${ }^{4}$ Department of Genetics and Pathology, ${ }^{5}$ Department of Hygiene and Epidemiology, ${ }^{6}$ Department of Rheumatology, Pomeranian Medical University, Szczecin, Poland; ' ${ }^{D}$ epartment of Surgery, University of Düsseldorf, Düsseldorf, Germany; ${ }^{3} T h e$ Danish HNPCC Register, Department of Surgical Gastroenterology, Hvidovre Hospital, University of Copenhagen, Denmark; 'Department of General Surgery, Medical University, Bydgoszzz, Poland; ${ }^{8}$ Department of Surgical Gastroenterology, Medical College, Jagiellonian University, Cracow, Poland

Key words: HNPCC, diagnosis

Corresponding author: Assoc. Professor Józef Kładny, Department of Surgical Oncology, Pomeranian Medical University, al. Powstańców Wlkp. 72,70-111 Szczecin, Poland. Fax: +4891 4661157, e-mail: jkladny@sci.pam.szczecin.pl

\begin{abstract}
The criteria for the diagnosis of HNPCC established by the ICG-HNPCC are very restrictive as they do not allow for the diagnosis of a large number of "suspected HNPCC" cases - these are families which do no fulfill the strict diagnostic "Amsterdam criteria", but do present with several pedigree and clinical features characteristic for HNPCC. Several series of families suspected of harboring germline mutations in DNA mismatch repair genes have been studied for germline changes in DNA mismatch repair genes and a mutation rate of somewhere between $8-60 \%$ was found. Therefore a subgroup of members of the ICG-HNPCC has been working on pedigree/clinical diagnostic criteria for suspected HNPCC.

Material and methods.

Part I. The study was based on two series of colorectal cancer (CRC) cases: 1) HNPCC - this group comprised 190 patients affected by CRC from randomly selected families which fulfilled the Amsterdam II criteria registered in Düsseldorf, Germany (102 cases of CRC), Denmark (18 CRCs), Leiden, Holland (23 CRCs) and Szczecin, Poland (47 CRCs). 2) Consecutive CRCs - this group comprised 629 (78.0\%) of 806 individuals with CRC diagnosed in 1991-1997 in the city of Szczecin (ca. 400,000 of inhabitants), Poland. Nuclear pedigrees in both groups were compared for frequency of occurrence of clinical features, that have been shown to be associated with HNPCC.

Part II. 52 consecutive CRC cases from Szczecin, matching the criteria recognized in part I as appropriate for diagnosis of cases "suspected of HNPCC" were studied for the occurrence of germline hMSH2/hMLH1 constitutional mutations using "exon by exon" sequencing.

Results. The combination of features - i.e. the occurrence of an HNPCC associated cancer (CRC or cancer of the endometrium, small bowel or urinary tract) in a 1st degree relative of a CRC patient; at least one of the patients being diagnosed under age of 50 - appeared to be strongly associated to HNPCC with an OR - 161 . Constitutional mutations were identified in 18 (10 MLH1 and $8 \mathrm{MSH} 2$ mutations) of 52 (34\%) cases matching the above features.

Conclusions. The results of our studies strongly suggest that it is possible to diagnose HNPCC with a high degree of accuracy on the basis of nuclear pedigree data and clinical features.
\end{abstract}


Hereditary non-polyposis colorectal cancer (HNPCC - Lynch syndrome) is an autosomal dominant disorder characterized by the development of colorectal cancer at an early age, a preponderance of tumors in the proximal colon, and an excess of multiple primary cancers [1]. In families with HNPCC extra-colonic tumors such as cancers of the endometrium, small bowel, hepatobiliary tract, urinary tract, ovary, stomach or brain occur with increased frequency [2-5]. Although genes related to the predisposition of HNPCC have already been cloned (hMLH1, hMSH2, hPMS2, hMSH6, and hMLH3), the detailed analysis of pedigree and clinical data remains crucial for the diagnosis of this disorder when determining a person's qualification for surveillance and gene testing [6-10]. According to the International Collaborative Group on HNPCC (ICG-HNPCC) the disease can be diagnosed when the Amsterdam criteria are matched, these being: 1) three or more relatives with histologically verified colorectal cancer (CRC), one of whom is first degree to the other two; 2) colorectal cancer affecting at least two generations, and 3) one or more colorectal cancer cases diagnosed under the age of 50 and 4) familial adenomatous polyposis is excluded [11].

The ICG-HNPCC criteria were revised in 1999 [12]. The term "colorectal cancer" was changed to "HNPCC-associated cancer". HNPCC-associated cancers include colorectal cancer and cancers of the endometrium, small bowel, renal pelvis or ureter.

The ICG-HNPCC criteria for the diagnosis of HNPCC are very restrictive and they do not allow for the inclusion of a large number of "suspected HNPCC" cases - that is families that do not fulfill the Amsterdam criteria, but present with several pedigree and clinical features characteristic of HNPCC. In several different series of families suspected of HNPCC but not fulfilling the diagnostic criteria, germline mutations were found in $8-60 \%$ of kindreds [13-17]. Therefore a subgroup of members of the ICG-HNPCC has been working on a pedigree/clinical diagnostic protocol for suspected cases of HNPCC. Recently, such criteria (shown in Table 1) were revised by Park et al. [16].

Park et al. (1999) agree that further refinements of the criteria are needed to improve the identification of HNPCC families. In our experience the most important limitations in the application of pedigree/clinical data in the diagnosis of HNPCC are problems with the availability of medical documentation of patients' relatives and the small size of contemporary families.

Therefore, in the study reported here we aimed to identify criteria based on nuclear pedigree and clinical analyses whilst maintaining the diagnosis of HNPCC with a high degree of sensitivity and specificity.

\section{Material and methods}

\section{Part I}

The study was based on two series of CRC cases:

1) HNPCC - this group comprised 190 patients affected by CRC from randomly selected families, which fulfilled the Amsterdam II criteria registered in Düsseldorf, Germany (102 cases of CRC), Denmark

Table 1. Revised criteria for the identification of suspected HNPCC

One colorectal cancer patient with at least one of the following:

Presence of synchronous or metachronous colorectal tumors in the patient, one of which occurred under the age of 40 years.

Endometrial, urinary tract, or small-intestinal cancer in the patient or a first degree relative (one aged $<50$ years).

At least two first degree relatives (one aged $<50$ years) with other extra-colonic cancers (stomach, hepatobiliary system, ovary, or brain).

Table 2. Definition of analysed pedigree/clinical features

\begin{tabular}{cl}
\hline Feature No & Definition \\
\hline F1 & at least one first degree relative of the index patient with CRC affected by an HNPC closely associated cancer* \\
\hline F2 & $\begin{array}{c}\text { at least one other malignancy associated with HNPCC (cancers of the stomach, hepatobiliary tract, ovary, pancreas } \\
\text { or gliomas) in a first degree relative of patient with CRC }\end{array}$ \\
\hline F3 & CRC diagnosed under the age of 50 \\
\hline F5 & HNPC diagnosed under the age of 40 \\
\hline * of the colon, rectum, endometrium, small bowel, urinary tract.
\end{tabular}


HNPCC Family (Mutation hMLH1)

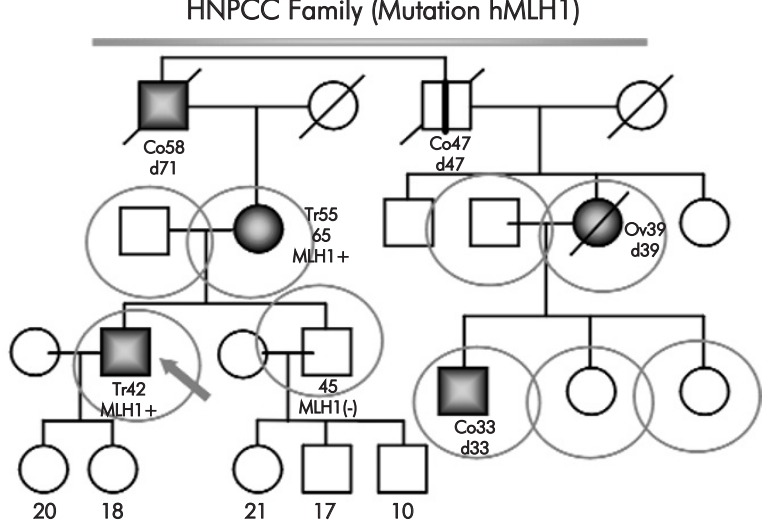

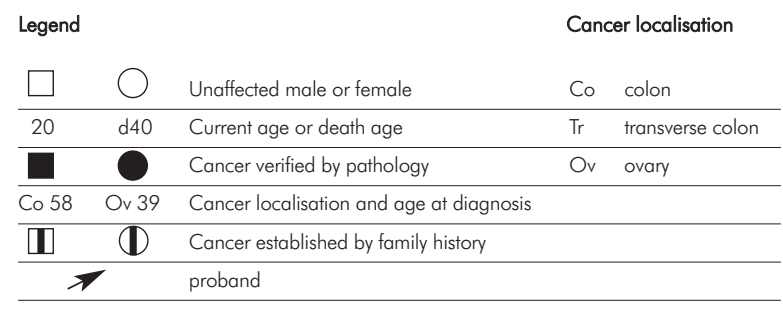

Fig. 1. Selection of cases for nuclear pedigree analysis. Individuals chosen are encircled
(18 CRCs), Leiden, Holland (23 CRCs) and Szczecin, Poland $(47$ CRCs). For 43 of these patients, information about the occurrence of constitutional MSH2 or MLH1 mutations were obtained. Patients for analysis from a given family were selected only from the youngest generation of individuals affected by cancers (Fig. 1). This selection system was chosen in order to avoid bias related to improvements in diagnostic procedures (colonoscopies were less frequently performed 10 years earlier) and potential anticipation of age at diagnosis in recent generations.

2) Consecutive CRCs - this group comprised 629 (78.0\%) of 806 individuals with recently diagnosed CRC in 1991-1997 in the city of Szczecin (ca. 400,000 of inhabitants), Poland.

Nuclear pedigrees in both groups were compared for the occurrence of clinical features that have been shown to be associated with HNPCC. The analyzed features are summarized in Table 2.

Univariate statistical analyses $-X^{2}$, odds ratio $(O R)$, confidence interval $(\mathrm{CI})$ - 95\%, sensitivity and specificity were performed using SAS program and LOGIT method.

\section{Part II}

52 consecutive CRC cases from HCC in Szczecin, matching F1, (F3 and/or F5) but not Amsterdam II criteria were studied for the occurrence of germline hMSH2/hMLH1 constitutional mutations using "exon by exon" sequencing.

Table 3. Statistical analysis of nuclear pedigree clinical features of CRC patients from HNPCC families in total

\begin{tabular}{|c|c|c|c|c|c|c|c|c|c|c|}
\hline Criterium & $\begin{array}{c}\text { No. } \\
\text { of HNPCC } \\
\text { cases }\end{array}$ & & $\begin{array}{l}\text { No. } \\
\text { of consecutive } \\
\text { cases }\end{array}$ & & OR & $\mathrm{Cl}$ & & sensitivity & specificity & $p$ \\
\hline Total & 182 & $\%$ & 629 & $\%$ & & from & to & $\%$ & $\%$ & \\
\hline $\mathrm{Fl}$ & 176 & 96.70 & 100 & 15.90 & 155.2 & 66.9 & 359.9 & 96.70 & 84.10 & 0.0000 \\
\hline F2 & 7 & 3.85 & 55 & 8.74 & 0.42 & 0.19 & 0.9 & 3.85 & 91.26 & 0.0490 \\
\hline F3 & 142 & 78.02 & 102 & 16.22 & 18.3 & 12.2 & 27.6 & 78.02 & 83.78 & 0.0000 \\
\hline F4 & 70 & 38.46 & 24 & 3.82 & 15.8 & 9.5 & 26.1 & 38.46 & 96.18 & 0.0000 \\
\hline F5 & 134 & 73.63 & 43 & 6.84 & 38 & 24.2 & 59.8 & 73.63 & 93.16 & 0.0000 \\
\hline $\begin{array}{l}\text { F1 without } \\
\text { (F3 or/and F5)* }\end{array}$ & 6 & 3.30 & 80 & 12.7 & 0.23 & 0.10 & 0.55 & 3.30 & 87.3 & 0.0003 \\
\hline $\begin{array}{l}\mathrm{F} 1 \text { and } \\
(\mathrm{F} 3 \text { or/and } \mathrm{F} 5)^{* *}\end{array}$ & 170 & 93.41 & 51 & 8.16 & 160.6 & 84.2 & 305.5 & 93.41 & 91.84 & 0.0000 \\
\hline $\begin{array}{l}\mathrm{F} 4 \text { without } \mathrm{Fl} \\
\text { and without } \mathrm{F} 22^{* * *}\end{array}$ & 2 & 1.10 & 38 & 6.04 & 0.17 & 0.04 & 0.72 & 1.10 & 93.96 & 0.0160 \\
\hline
\end{tabular}


Table 4. Statistical analysis of nuclear pedigree clinical features of CRC patients with identified mutations

\begin{tabular}{|c|c|c|c|c|c|c|c|c|c|c|}
\hline Criterion & $\begin{array}{l}\text { No. } \\
\text { of HNPCC } \\
\text { cases }\end{array}$ & & $\begin{array}{c}\text { No. } \\
\text { of consecutive } \\
\text { cases }\end{array}$ & & OR & $\mathrm{Cl}$ & & sensitivity & specificity & $p$ \\
\hline Total & 43 & $\%$ & 629 & $\%$ & & from & to & $\%$ & $\%$ & \\
\hline $\mathrm{Fl}$ & 39 & 90.70 & 100 & 15.90 & 51.6 & 18.03 & 147.5 & 90.70 & 84.10 & 0.0000 \\
\hline F2 & 5 & 11.63 & 54 & 8.59 & 1.4 & 0.53 & 37.1 & 11.63 & 91.41 & 0.4970 \\
\hline F3 & 41 & 95.35 & 102 & 16.22 & 105.9 & 25.22 & 444.8 & 95.35 & 83.78 & 0.0000 \\
\hline F4 & 26 & 60.47 & 24 & 3.82 & 38.5 & 18.5 & 80.4 & 60.47 & 96.18 & 0.0000 \\
\hline F5 & 30 & 69.77 & 43 & 6.84 & 31.4 & 15.3 & 64.65 & 69.77 & 93.16 & 0.0000 \\
\hline $\begin{array}{l}\mathrm{F} 1 \text { without } \\
(\mathrm{F} 3 \text { or/and } \mathrm{F} 5)^{*}\end{array}$ & 1 & 2.33 & 81 & 12.88 & 0.16 & 0.02 & 1.19 & 2.33 & 87.12 & 0.0408 \\
\hline $\begin{array}{l}\mathrm{Fl} \text { and } \\
(\mathrm{F} 3 \text { or/and } \mathrm{F} 5)^{* *}\end{array}$ & 39 & 90.70 & 51 & 8.16 & 110.5 & 39.4 & 307.9 & 90.70 & 91.84 & 0.0000 \\
\hline $\begin{array}{l}\mathrm{F} 4 \text { without } \mathrm{F} 1 \\
\text { and without } \mathrm{F} 2^{* * *}\end{array}$ & 2 & 4.65 & 18 & 2.86 & 1.66 & 0.37 & 7.38 & 1.09 & 97.13 & 0.5041 \\
\hline $\begin{array}{l}\text { * HNPCC closely asso } \\
* * * \text { HNPCC closely ass } \\
\text { *** sporadic CRC diag }^{*}\end{array}$ & $\begin{array}{l}\text { d cancer in } f \\
\text { ed cancer in } \\
\text { ed under the }\end{array}$ & $\begin{array}{l}\text { degree } r \\
\text { t degree } \\
\text { of } 40 \text {. }\end{array}$ & $\begin{array}{l}\text { ative of } C R C \text { pati } \\
\text { lative of } C R C \text { pa }\end{array}$ & $\begin{array}{l}\text { t; none o } \\
\text { nt; at lea }\end{array}$ & $\begin{array}{l}\text { ese cance } \\
\text { he of can }\end{array}$ & $\begin{array}{l}\text { were dias } \\
\text { rs was did }\end{array}$ & $\begin{array}{l}\text { gnosed u } \\
\text { agnosed }\end{array}$ & $\begin{array}{l}\text { der the age } 0 \\
\text { nder the age }\end{array}$ & $\begin{array}{l}50 . \\
\text { of } 50 .\end{array}$ & \\
\hline
\end{tabular}

\section{Results}

The results of the genomic DNA sequencing analyses are summarized in Table 3. All of the defined features (F1-F5) were confirmed to be very strongly associated to HNPCC with an OR of 15 to 155 depending on which feature was chosen for the clinical and or pedigree diagnosis. The only exception was feature F2, where it was impossible to show that the occurrences of cancers of the stomach, hepatobiliary tract, ovary, pancreas or gliomas among first degree relatives of CRC patients are characteristic for HNPCC (OR - 0.42). The strongest association to HNPCC was the occurrence of one first degree relative with one of either colon, rectum, endometrium, small bowel or urinary tract cancer $\mathrm{OR}$ 155.2. However, aggregation of at least two first degree relatives affected by an HNPCC associated cancer has been shown not to be characteristic of HNPCC in families who do not have disease diagnosed under the age of 50 years (OR - 0.23).

In contrast, combining features $\mathrm{Fl}$ and (F3 and/or F5) - a situation where an HNPCC closely associated cancer is found in first degree relatives of CRC patients and one of these cancers is diagnosed under age of 50 , appeared to be strongly associated with HNPCC $(O R-161)$. The occurrence of sporadic cancer diagnosed under the age of 40 years (combinations F4 without Fl and without F2) has been found not to be characteristic of HNPCC (OR - 0.17).
Similar features and their combinations have been recognized as being typical of HNPCC in a subgroup of 43 cases from families with confirmed MSH2 or MLH1 constitutional mutations (Table 4). Constitutional mutations were identified in 18 (10 MLH1 and $8 \mathrm{MSH} 2$ mutations) of 52 (34\%) cases matching the combination of features, F1 and (F3 and/or F5).

\section{Discussion}

The results of our studies strongly suggest that it is possible to diagnose HNPCC with a high degree of accuracy on the basis of nuclear pedigree data and clinical features alone. One simple criterion - the occurrence of two or more HNPCC closely associated cancers (cancer of the colon, rectum, endometrium, small bowel and urinary tract) in first degree relatives of patients with CRC with at least one of the cancers is diagnosed under the age of 50 - can be used to identify HNPCC with an OR - 161. Unexpectedly, we found that the diagnosis of suspected HNPCC is not possible on the basis of nuclear pedigree analysis alone if patients with CRC are diagnosed under the age of 40 and without a first degree relative affected by an HNPCC associated malignancy.

The analyses performed in this report are an alternative approach for the diagnosis of HNPCC on clinical criteria based on the statistical assessment of the frequency of specifically analyzed features between the study population and control groups of patients 
with CRC. Previous studies by Percesepe et al. were performed using a different methodology [17]. For the assessment of independent significance of each feature they applied multivariate analysis. In order to exclude potential errors of their analyses we decided to apply in our approach the more direct verification of early onset of CRC as an independent HNPCC predictor by excluding from the analysis the "age at diagnosis" in cases that matched other criteria.

The methodologies applied in the current study were undertaken because results of a molecular search for MSH2/MLH1 mutations were simultaneously performed in our center - in none of the 10 sporadic CRCs diagnosed under the age of 40 , were we able to detect molecular genetic changes. Thus, together with results of nuclear pedigree studies presented herein, we have verified the utility of nuclear pedigree criteria for the identification of HNPCC families.

Park et al. reported the occurrence of $M S H 2 / M L H 1$ mutations among $6 \%$ (3 of 50 cases) of sporadic early onset CRCs [16]. The proportion of mutations in HNPCC genes in unselected CRCs is between 2-3\%. The results reported by Park et al. suggest that in patients with sporadic early onset CRC the probability of finding DNA mismatch repair gene mutations is more than twice as high. In relation to our results, Park's findings can be explained by a bias brought about by the small number of cases used in their study.

The results of our study strongly indicate that caution must be taken in defining the criteria of diagnosis for genetic disorders and the usefulness of the methodological approach developed in this report. Wherever possible, analyses for independent significance of the studied features should be verified by the construction of subgroups that define the potential criteria for selection.

We believe that the criteria defined in this report can be further improved. There are several other pedigree/clinical features of potential diagnostic significance such as, right-sided tumor localization, tumor multiplicity or mucinous histology of CRC [17].

In order to develop more accurate criteria it is crucial to register a much larger number of HNPCC cases displaying a series of specific features. In our experience, nuclear pedigree criteria of suspected HNPCC defined in this paper are of enormous practical significance for the identification of HNPCC families subsequent to DNA testing and surveillance.

\section{References}

1. Lynch HT, Lanspa SJ, Boman BM, Smyrk T, Watson P, Lynch JF, Lynch PM, Cristofaro G, Bufo P, Tauro AV, Mingazzini P, Di Giulio E. Hereditary Nonpolyposis Colorectal Cancer - Lynch Syndromes I and II. Gastroent Clin North Am 1988; 17: 679-712.

2. Benatti P, Sassatelli R, Roncucci L, Pedroni M, Fante R, Did Gregorio C, Losi L, Gelmini R, Ponz de Leon M. Tumor spectrum in Hereditary Non-Polyposis Colorectal Cancer (HNPCC) and in families with "suspected HNPCC". A population-based study in northern Italy. Int J Cancer 1993; 54: 371.

3. Lynch HT, Kriegler M, Christiansen TA, Smyrk T, Lynch JF, Watson P. Laryngeal carcinoma in a Lynch syndrome II kindred. Cancer 1988; 62: 1007.

4. Lynch HT, Voorhees GM, Lanspa SJ, Greevy PS, Lynch JF. Pancreatic carcinoma and hereditary nonpolyposis colorectal cancer: a family study. Br J Cancer 1985; 52: 271.

5. Aarnio M, Sankila R, Pukkala E, Salovaara R, Aaltonen L A, De La Chapelle A. Cancer risk in mutation carriers of DNAmismatch-repair genes. Int J Cancer 1999; 81: 214-18.

6. Leach FS, Nicolaides NC, Papadopoulos N, Liu B, Jen J, Parsons R, Peltomaki P, Sistonen P, Aaltonen LA, Nystrom-Lahti M, Guan XY, Zhang J, Meltzer PS, Yu JW, Kao FT, Chen DJ, Cerosaletti KM, Keith Fournier RE, Todd S, Lewis T, Leach RJ, Naylor SL, Weissenbach, Mecklin JP, Järvinen H, Petersen GM, Hamilton SR, Green J, Jass J, Watson P, Lynch HT, Trent JM, de la Chapelle A, Kinzler KW, Vogelstein B. Mutations of a mutS homolog in hereditary nonpolyposis colorectal cancer. Cell 1993; 75: 1215-25.

7. Papadopoulos N, Nicolaides NC, Wei YF, Ruben SM, Carter KC, Rosen CA, Haseltine WA, Fleischmann RD, Fraser CM, Adams MD, Venter JC, Hamilton SR, Petersen GM, Watson P, Lynch HT, Peltomäki P, Mecklin JP, de la Chapelle A, Kinzler KW, Vogelstein B. Mutation of a mutL homolog in hereditary colon cancer. Science 1994; 263: 1625-9.

8. Nicolaides NC, Papadopoulos N, Liu B, Wei YF, Carter KC, Ruben SM, Rosen CA, Haseltine WA, Fleischmann RD, Fraser CM, Adams MD, Venter JC, Dunlop MG, Hamilton SR, Petersen GM, de la Chapelle A, Vogelstein B, Kinzler KW. Mutations of two PMS homologues in hereditary nonpolyposis colon cancer. Nature 1994; 371: 75-80.

9. Akiyama Y, Sato H, Yamada T, Nagasaki H, Tsuchiya A, Abe R, Yuasa Y. Germ-line mutation of the hMSH6/GTBP gene in an atypical HNPCC kindred. Cancer Res 1997; 57: 3920-3.

10. Lu SL, Kawabata M, Imamura T, Akiyama Y, Nomizu T, Miyazono $K$, Yuasa Y. HNPCC associated with germline mutation in the TGF-B type II receptor gene. Nature Genet 1998; 19: 17-18.

11. Vasen HFA, Mecklin J-P, Meera Khan P, Lynch HT. The International Collaborative Group on Hereditary Non-Polyposis Colorectal Cancer (ICG-HNPCC). Dis Colon Rectum 1991; 34: 424-425.

12. Vasen HFA, Watson P, Mecklin JP, Lynch HT. New clinical criteria for hereditary nonpolyposis colorectal cancer (HNPCC, Lynch syndrome) proposed by the International Collaborative Group on HNPCC. Gastroenterology 1999; 116: 1453-6.

13. Wang Q, Lasset C, Desseigne F, Saurin JC, Maugard C, Navarro C, Ruano E, Descos L, Trillet-Lenoir V, Bosset JF, Puisieux A. Prevalence of germline mutations of hMLH1, hMSH2, hPMS1, hPMS2, and hMSH6 genes in 75 French kindreds with nonpolyposis colorectal cancer. Hum Genet 1999; 105: 79-85.

14. Heinimann K, Scott RJ, Buerstedde JM, Weber W, Siebold K, Attenhofer M, Muller H, Dobbie Z. Influence of selection criteria on mutation detection in patients with hereditary nonpolyposis colorectal cancer. Cancer 1999; 85: 2512-18.

15. Moslein G, Tester DJ, Lindor NM, Honchel R, Cunningham JM, French AJ, Halling KC, Schwab M, Goretzki P, Thibodeau SN. Microsatellite instability and mutation analysis of hMSH2 and $\mathrm{hMLH} 1$ in patient with sporadic, familial and hereditary colorectal cancer. Hum Mol Genet 1996; 5: 1245-52.

16. Park JG, Vasen HFA, Park KJ, Peltomaki P, Ponz de Leon M, Rodriquez-Bigas MA, Lubinski J, Beck NE, Bisgaard ML, Miyaki M, Wijnen JT, Baba S, Lynch HT. Suspected Hereditary Nonpolyposis Colorectal Cancer. Dis Colon Rectum 1999; 42: 710-716.

17. Percesepe A, Anti M, Marra G, Roncucci L, Pahor M, Coco C, Armelao F, Gasparrini G, Ponz de Leon M. Role of clinical criteria in the diagnosis of hereditary non-polyposis colorectal cancer (HNPCC): results of a multivariate analysis. Int J Cancer 1994; 58: 799-802. 